\title{
Multimedia Interaktif Pengenalan Pura Paluang Nusa Penida Bali Berbasis Android
}

\author{
I Wayan Gede Oksarya Ega Satrya ${ }^{1}$, I Gede Suardika ${ }^{2}$, Ni Kadek Sukerti ${ }^{3}$, Ni Putu Nanik Hendayanti ${ }^{4}$ \\ 1,2,3,4 Sistem Informasi, Fakultas Informatika dan Komputer, Instititut Teknologi dan Bisnis STIKOM Bali \\ 1 ega_sobb@yahoo.com , ${ }^{2}$ suardika@stikom-bali.ac.id *, ${ }^{3}$ dektisamuh@stikom-bali.ac.id , ${ }^{4}$ nanik@stikom-bali.ac.id
}

\begin{abstract}
Paluang Temple, which is located in Nusa Penida District, Klungkung Regency, Bali, in the Karangdawa Hamlet area, Bungamekar Village has two "pelinggih" which are slightly less common than other temples in Bali because their shape resembles a Jimny and VW Beatle type car. Until now, information about Paluang Temple is still in the form of articles containing the history and uniqueness of Paluang Temple. One of the ways to introduce the potential of historical, spiritual and cultural knowledge in Paluang Temple is through the media of Information Technology (IT) which is packaged in Androidbased Interactive Multimedia, which is expected to be a forum for educational and attractive information that is easily accessible by the general public, and Hindus in particular. The research method used is research with the research method of $R \& D$ (Research and Development). The method used to develop interactive multimedia is the Multimedia Development Life Cycle $(M D L C)$ method and there are 6 stages, namely concept, design, material collecting, assembly, and testing. Interactive Multimedia Application Introduction to Paluang Temple Nusa Penida - Klungkung Based on Android was tested by the Blackbox method has been running as expected, the application functionality is also functioning properly.
\end{abstract}

Keywords: Temple, Interactive Multimedia, MDLC

\begin{abstract}
Abstrak
Pura Paluang yang terletak di Kecamatan Nusa Penida, Kabupaten Klungkung Bali, tepatnya di kawasan Dusun Karangdawa, Desa Bungamekar memiliki dua pelinggih (bangunan suci) yang sedikit kurang lazim bentuknya dibandingkan pura-pura lain pada umumnya di Bali. Jika pelinggih umumnya di pura-pura berbentuk seperti candi, maka bentuk pelinggih di Pura Paluang menyerupai mobil jenis Jimny dan VW Beatle. Sampai saat ini informasi mengenai Pura Paluang ini masih berupa artikelartikel yang berisi mengenai sejarah dan keunikan Pura Paluang tersebut. Untuk memperkenalkan potensi pengetahuan sejarah, spiritual dan budaya yang ada di Pura Paluang salah satunya adalah melalui media Informasi Teknologi (IT) yang dikemas dalam Multimedia Interaktif Berbasis Android, yang diharapkan dapat menjadi wadah Informasi yang edukatif serta atraktif yang mudah di akses oleh masyarakat pada umumnya dan umat Hindu pada khususnya. Metode penelitian yang dilakukan adalah penelitian dengan metode penelitian R\&D (Research And Development). Metode yang digunakan untuk mengembangkan multimedia interaktif ini adalah metode Multimedia Development Life Cycle (MDLC) dan terdapat 6 tahapan, yaitu concept, design, material collecting, assembly, dan testing. Aplikasi Multimedia Interaktif Pengenalan Pura Paluang Nusa Penida - Klungkung Berbasis Android dalam pengujian menggunakan metode Blackbox sudah berjalan sesuai dengan yang diharapkan, fungsionalitas aplikasi juga sudah berfungsi dengan baik.
\end{abstract}

Kata kunci: Pura, Multimedia Interaktif, MDLC.

\section{a. Pendahuluan}

Pura di Bali adalah tempat suci untuk memusatkan konsentrasi oleh umat Hindu dalam setiap melakukan persembahyangan [1]. Mendengar kata Pura sudah tentu terlintas pikiran kita akan tertuju dengan bentuk bangunan suci masyarakat Hindu yang berbentuk seperti candi. Namun, berbeda dengan Pura Paluang yang terletak di Kecamatan Nusa Penida, Kabupaten Klungkung, di kawasan Dusun Karangdawa, Desa Bungamekar.

Pura Paluang di Nusapenida Klungkung ini jaraknya jauh dari area pemukiman warga dan saat memasuki areal pura ada beberapa bangunan yang akan dijumpai seperti dapur, tempat peristirahatan pemangku, dua wantilan, serta tangki air yang berada di sebelah candi bentar pura sedangkan untuk area jeroan (dalam) pura terdapat 13 pelinggih yang sebagian besar terbuat dari batu paras putih khas Nusa Penida.
Sekilas keberadaan Pura ini tidak ada bedanya dengan Pura di Bali pada umumnya. Tapi bila dicermati, ternyata ada dua pelinggih di dalam Pura tersebut sedikit kurang lazim bentuknya. Karena pelinggih yang dibangun menyerupai mobil jenis Jimny dan VW Beatle. Pelinggih mobil ini adalah altar pemujaan sebagai simbol stana manifestasi Tuhan Ida Bhatara Ratu Gede Sakti Ngurah dan Hyang Mami atau Siwa Durga di Pura Paluang Nusa Penida [2].

Pelinggih yang berbentuk Mobil VW Beatle berada di atas sebuah panggung, lengkap dengan ukiran pada bagian sisinya. Mobil ini dipoles berwarna emas pada bagian kap, dan coklat kekuningan pada bagian badan mobil. Berjarak tidak jauh dari mobil VW, terdapat mobil Jimmy yang tampak bercat merah dan bagian lainnya berwarna abu-abu seperti warna dasar semen dengan kaca depan tertutup, dan terdapat dua naga berwarna hijau emas kedua sisinya serta di depannya terdapat meja untuk tempat menghaturkan sesaji. Setiap mobil berisikan plat nomor kendaraan, KD 013 untuk 
plat mobil VW Beatle dan DK 28703 GL untuk plat mobil Jimny.

Pura Paluang pada awalnya hanyalah pura kecil yang berdiri dalam satu mandala saja dan bukan termasuk pura yang diperhitungkan dalam jajaran pura kahyangan Dusun Karang Dawa, Desa Bunga Mekar, Nusa Penida. jagat di Nusa Penida dan hanya berstatus pura keluarga Peneliti memilih lokasi ini, karena masih belum banyak [2]. Sampai saat ini informasi mengenai Pura Paluang ini informasi mengenai Pura Paluang Nusa Penida tersebut masih berupa artikel-artikel yang berisi mengenai sejarah, dan keunikan Pura Paluang tersebut.

Saat ini dunia teknologi informasi sudah berkembang pesat dari waktu ke waktu sebagai media pembelajaran maupun sarana pendukung pengetahuan, salah satunya melalui Multimedia Pembelajaran. Multimedia dapat langkah yang dilakukan untuk merancang "Aplikasi didefinisikan sebagai gabungan dari unsur teks, grafik, Multimedia Interaktif Pengenalan Pura Paluang Nusa audio, video, dan animasi untuk menghasilkan Penida-Bali Berbasis Android" dengan menggunakan presentasi[3] yang mengkombinasikan media visual metode Multimedia Development Life Cycle (MDLC) (penglihatan) dan audio (pendengaran) [4].

Maka dalam hal itu untuk memperkenalkan potensi pengetahuan sejarah, spiritual dan budaya yang ada di Pura Paluang salah satunya adalah melalui media Informasi Teknologi (IT) yang dikemas dalam ti Multimedia Interaktif Berbasis Android, yang konsep program dalam perancangan Aplikasi diharapkan dapat menjadi wadah Informasi yang Multimedia Interaktif Pura Paluang Nusa Penida. Tahap edukatif serta atraktif yang mudah diakses oleh material collecting adalah tahap pengumpulan bahan masyarakat pada umumnya dan umat Hindu pada yang sesuai dengan kebutuhan yang dikerjakan. Bahankhususnya.

Berdasarkan uraian diatas, maka penelitian yang dibuat ini guna memberikan wawasan kepada masyarakat Bali khususnya Hindu terhadap keberadaan maupun keunikan Pura Paluang, maka dari tujuan penelitian tersebut dibuatkan "Multimedia Interaktif Pengenalan Pura Paluang Nusapenida Bali Berbasis Android" yang diharapkan menjadi media yang dapat memberikan informasi serta melestarikan Pura Paluang sehingga tetap menjaga kesucian maupun taksu dari Pura Paluang itu sendiri.

\section{b. Metode Penelitian}

Metode penelitian yang dilakukan adalah penelitian dengan metode penelitian R\&D (Research And Development). Pengembangan atau Research and Development (R\&D) adalah suatu proses pengembangan perangkat pendidikan yang dilakukan melalui serangkaian riset yang menggunakan berbagai metode dalam suatu siklus yang melewati berbagai tahapan [5]. Dalam penelitian yang akan dilakukan, metode penelitian ini dipilih penulis sesuai dengan tujuan penelitian yang ingin dicapai yaitu untuk menghasilkan suatu produk berupa Multimedia Interaktif Pengenalan Pura Paluang.

Pada perekayasaan ini digunakan teknik pengumpulan data yaitu studi literatur dan wawancara. Studi literatur dilakukan dengan cara mencari sumber data berupa artikel jurnal yang membahas tentang Pura Paluang Nusa Penida. Dalam tahapan wawancara pengumpulan data dilakukan dengan cara mewawancarai Jero Mangku Suar selaku pemangku adat di Pura Paluang Nusa lengkap mengenai sejarah maupun pembangunan Pura Paluang Nusa Penida.

yang diterapkan berupa aplikasi berbasis Andoid, serta tujuan lain penulis memilih lokasi ini ialah untuk memperkenalkan potensi pengetahuan sejarah, spiritual dan budaya yang ada di Pura Paluang.

dan terdapat 6 tahapan, yaitu concept, design, material collecting, assembly, dan testing [6].

Tahap concept adalah tahap untuk menentukan tujuan dan siapa pengguna program (identifikasi audiens). Pada tahap design berisikan pembuatan spesifikasi serta yang sesuai dengan kebutuhan yang dikerjakan. Bahan-
bahan tersebut antara lain gambar clip art, foto, animasi, video, audio, dan lain-lain yang didapatkan dari membaca buku dan mencari sumber-sumber lainnya dari internet. Tahap assembly (pembuatan) adalah tahap pembuatan semua objek atau bahan multimedia. Pembuatan aplikasi didasarkan storyboard, bagan alir, dan struktur navigasi.

Alat dan bahan yang digunakan pada pembuatan Aplikasi Multimedia Interaktif Pengenalan Pura Paluang Nusa Pendida ini adalah sebagai berikut: Perangkat Keras (Hardware) terdiri dari PC (Personal Computer) atau Laptop, Smartphone Android Versi 6.0 (Marshmallow). Perangkat lunak yang digunakan untuk merancang dan membuat Aplikasi Multimedia Interaktif Pengenalan Pura Paluang Nusa Penida adalah Adobe Flash CS6. Pada tahap testing, dilakukan pengujian menggunakan blackbox testing. Dalam tahap distribusi, aplikasi akan dirilis melalui marketplace penyedia aplikasi seperti Google Play dan dapat diunduh secara gratis.

\section{Hasil dan Pembahasan}

Dalam tahap pembuatan konsep penulis menggunakan anilisa $5 \mathrm{~W}+1 \mathrm{H}$, tujuan dari pada analisa ini adalah untuk dapat menyusun dan mengembangkan proses selanjutnya [7]. Adapun fungsi analisa $5 \mathrm{~W}+1 \mathrm{H}$ dari penelitian ini adalah sebagai berikut :

a. Apa isi dari aplikasi yang akan dibuat? (What)

Aplikasi yang akan dibuat memuat tentang pengenalan sejarah, serta pembangunan Pura Paluang Nusa Penida

b. Mengapa aplikasi ini dibuat? (Why) 
Aplikasi ini dibuat dengan tujuan untuk b. Ketika user memilih salah satu menu-menu yang memperkenalkan sejarah, pembangunan serta ada maka sistem akan menampilkan halamanspiritualisme Pura Paluang kepada masyarakat Hindu halaman sesuai menu yang dipilih.

khususnya yang berada di Bali

c. Fungsi dari pembuatan Aplikasi Multimedia Interaktif Pura Paluang Nusa Penida Berbasis Android ini diharapkan bisa memperkenalkan sejarah, pembangunan serta spiritualisme Pura Paluang kepada masyarakat Hindu khususnya yang berada di Bali.

Berdasarkan dari tujuan dibuatnya aplikasi ini, sasaran penggunanya adalah masyarakat Bali khususnya yang beragama Hindu yang ingin mengetahui lebih lanjut tentang sejarah maupun struktur pembangunan Pura Paluang Nusa Penida

d. Dimana aplikasi ini akan diimplementasikan ? (Where)

Aplikasi ini akan dibuat dengan output apk sehingga dapat digunakan pada platform smartphone dengan Android.

e. Kapan aplikasi ini dapat diimplementasikan ? (When)

Adapun beberapa kebutuhan non fungsional dari aplikasi ini, sebagai berikut.

a. Analisis perangkat keras bertujuan untuk mengetahui secara tepat perangkat keras yang dibutuhkan. Adapun perangkat keras yang dibutuhkan untuk membuat aplikasi ini adalah Laptop Lenovo T430, Sistem Operasi Windows 7, layar monitor 16 inchi, Intel(R) Core(TM) i5,RAM 4.00 GB (3.41 GB usable), Hardisk 1TB, 64-bit Operating System, x64-based processor.

b. Perangkat Lunak yang digunakan untuk membuat Aplikasi Multimedia Interaktif Pengenalan Pura Paluang Nusa Penida Klungkung Berbasis Android antara lain adalah Adobe Flash.

Aplikasi ini dapat diimplementasikan setelah melalui proses perancangan, pembuatan dan pengujian selesai. Setelah didistribusikan, maka aplikasi ini dapat diimplementasikan kapanpun oleh pengguna.

f. Bagaimana aplikasi ini dibuat? (How)

c. Perancangan Sistem merupakan perancangan alur sistem yang dibuat seperti perancangan Flowchart, Desain Interface dan Storyboard Video Animasi.

Aplikasi ini dibangun dengan cara mencari sumber- d. Perancangan Struktur Menu Aplikasi Multimedia sumber informasi yang berkaitan dengan penelitian serta melakukan wawancara dari nasumber yang terpercaya
Interaktif Pengenalan Pura Paluang Nusa Penida Klungkung Berbasis Android dapat dilihat pada

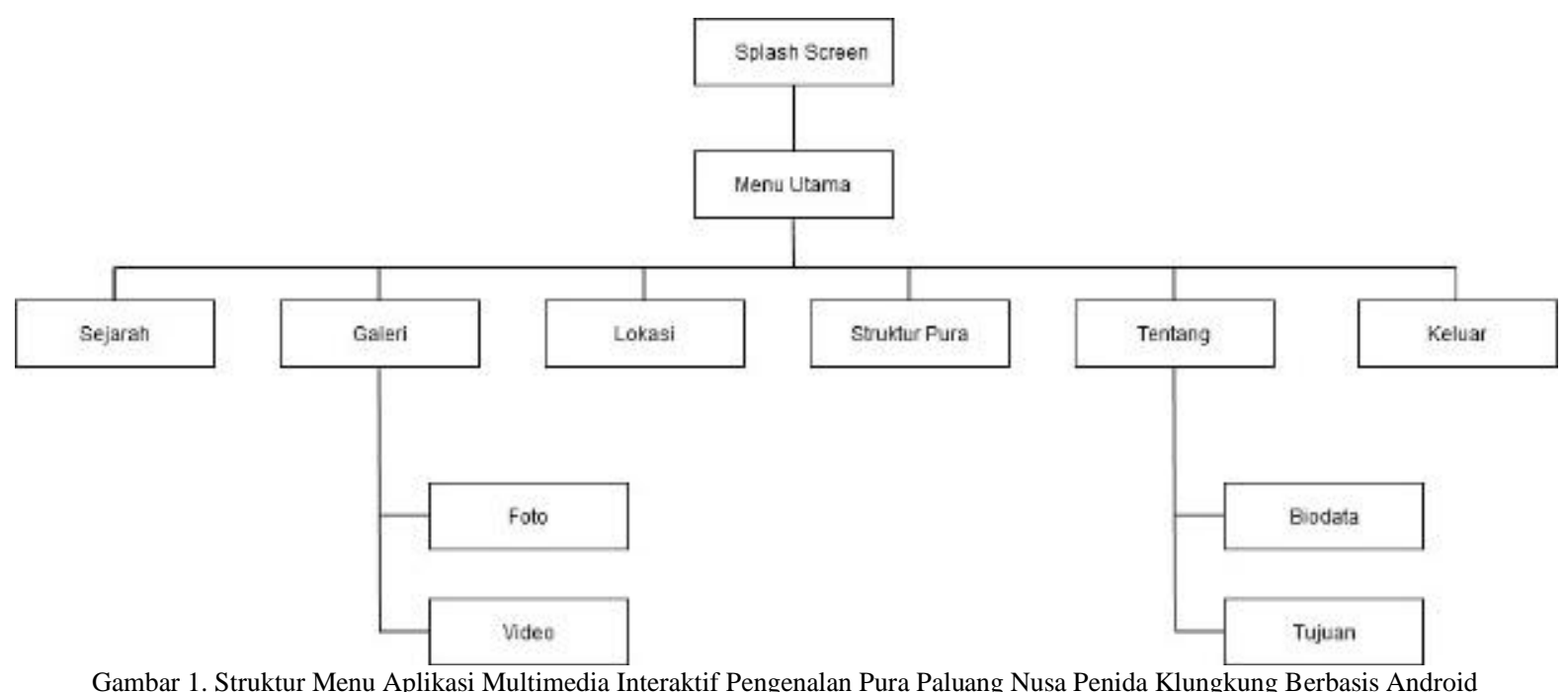

dan melakukan observasi langsung ke lokasi penelitian.

Gambar 1.

Hasil Analisa Kebutuhan sistem terdapat dua analisa Berikut merupakan penjelasan dari setiap menu-menu yang harus dipenuhi dalam pembuatan aplikasi, sebagai yang ada pada Aplikasi Multimedia Interaktif berikut: Pengenalan Pura Paluang Klungkung Berbasis Android:

Analisa Kebutuhan Fungsional merupakan kebutuhan Menu Sejarah akan menampilkann dua sub menu akan fasilitas yang dibutuhkan serta proses apa saja yang berupa menu Sejarah yang menjelaskan sejarah singkat dilakukan oleh sistem: mengenai Pura Paluang Nusa Penida dan menu Animasi yang akan memvisualisasikan dengan animasi 2D.

a. Saat user menjalankan aplikasi terdapat beberapa menu serta button yang akan di tampilkan.

Menu Galeri dimana menu galeri akan menampilkan dua sub menu seperti foto dan video tentang Pura Paluang 
Nusa Penida. Dalam menu foto dapat beberapa foto yang diambil di Pura Paluang dan terdapat keterangan di dalam foto tersebut. Menu Video terdapat sebuah video yang menjelaskan tentang Pura Paluang tersebut.

Menu Lokasi, terdapat informasi mengenai keberadaan lokasi Pura Paluang tersebut dan menu ini akan terhubung dengan aplikasi Google Maps.

Menu Struktur Pura berisi tentang gambar struktur serta penjelasan setiap pelinggih yang ada di Pura Paluang.

Menu Bantuan dimana pada menu bantuan akan terdapat informasi mengenai fungsi-fungsi pada setiap tombol yang ada di aplikasi.

Menu Profil dalam menu Profil akan terdapat informasi mengenai penulis.

Menu Keluar terdapat tombol untuk keluar pada aplikasi.

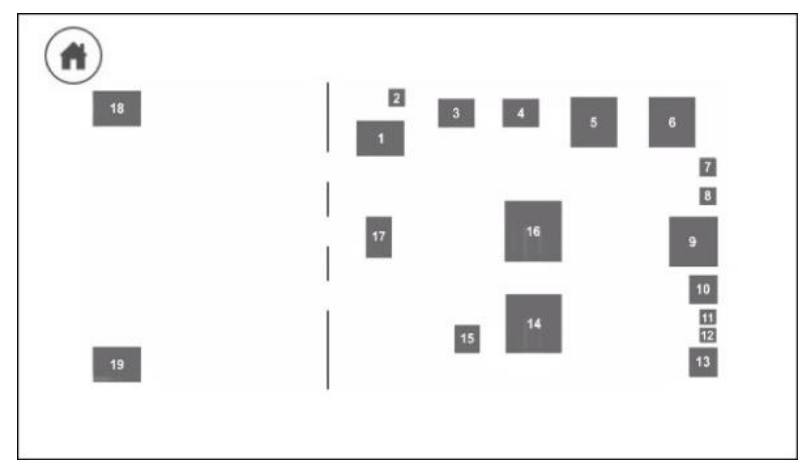

Gambar 2. denah pura pada aplikasi Multimedia Interaktif Pengenlan Pura Paluang Berbasis Android

Gambar 2 merupakan tampilan dari halaman denah pura pada aplikasi Multimedia Interaktif Pengenlan Pura Paluang Berbasis Android. Halaman denah pura memuat tentang informasi mengenai fungsi dan foto dari setiap pelinggih yang ada di Pura Paluang, pelinggih ditandai dengan nomor yang berfungsi sebagai tombol, jika user memilih salah satu tombol pada denah akan muncul foto dan penjelasan mengenai pelinggih pura paluang.

Storyboard adalah suatu sketsa gambar yang disusun dengan urut berdasarkan naskah cerita sehingga bisa mendapatkan persepsi yang sama dengan ide cerita yang dibuat [8]. Tabel 1 adalah salah satu storyboard alur cerita sejarah animasi pura Paluang Nusa Penida.

Tabel 1. Storyboard

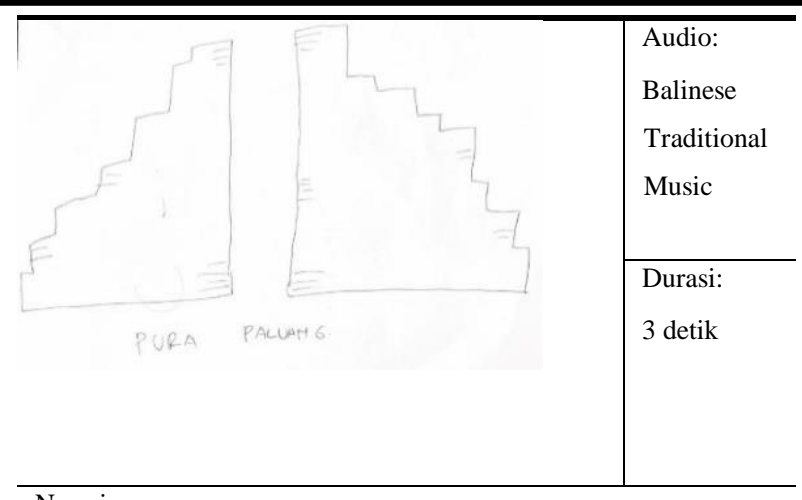

Narasi:

Pura itu adalah Pura Paluang.

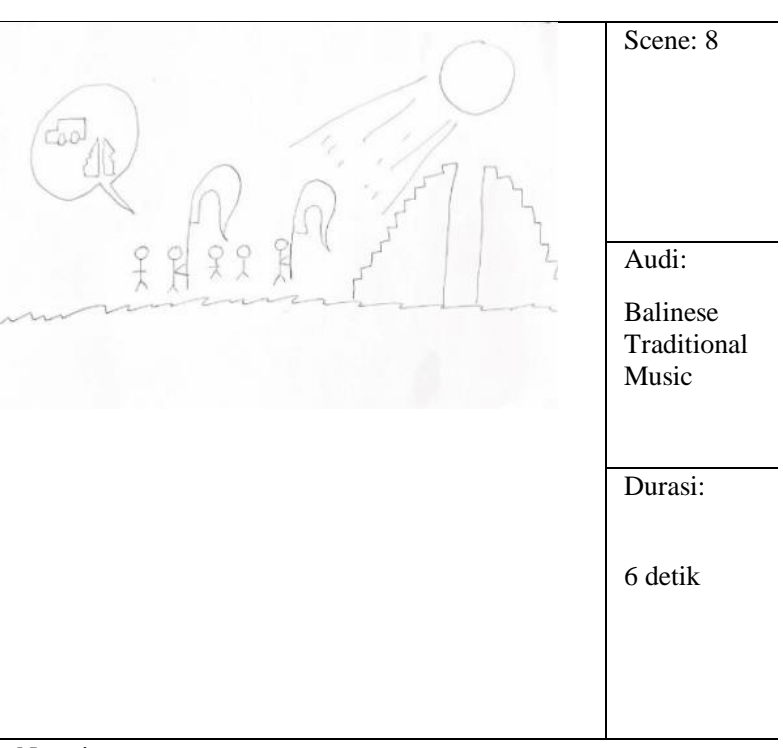

Narasi:

Dengan berjalannya waktu ada pawisik Ida yang melinggih di pura tersebut yaitu Ratu Gede Sakti Hyang Mami meminta agar masyarakat setempat membuatkan pelinggih mobil, karena beliau di alam niskala memiliki kendaraan berupa mobil.

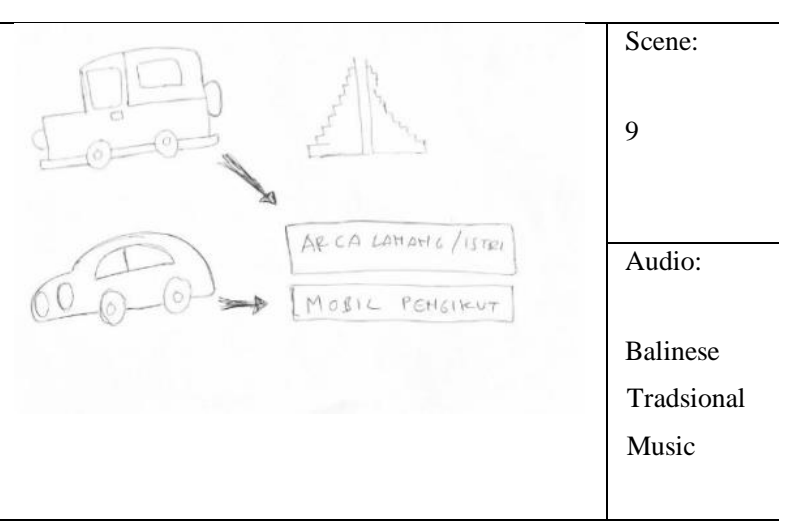




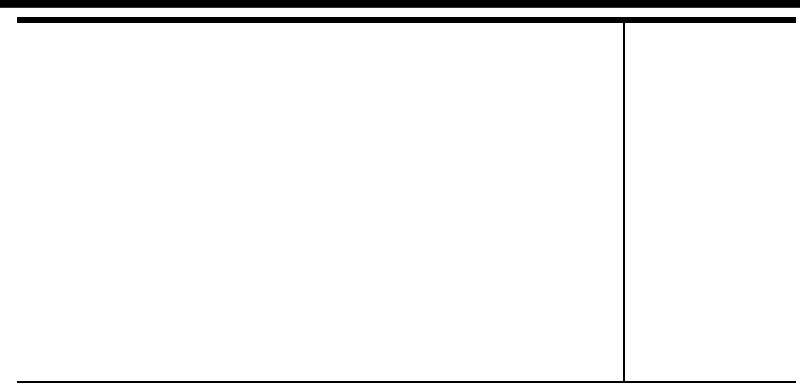

Mobil jimmy lah yang merupakan pelinggih dari Ratu Gede Sakti Hyang Mami. Dimana di dalam pelinggih mobil Jimmy terdapat 2 arca lanang istri yang diyakini warga setempat sebagai manifestasi Ida Bhatara yang melinggih yaitu Ida Bhatara Ratu Gede Ngurah dan Hyang Mami. Sementara mobil VW Beatle merupakan mobil dari pengikut atau anak-anak beliau.

Tahap assembly (pembuatan) dilakukan dengan menggabungkan ilustrasi serta pembuatan aplikasi yang sesuai dengan storyboard dan struktur navigasi yang bersumber dari tahapan desain. Dalam pembuatan perangkat lunak yang digunakan dalam membuat aplikasi yaitu Adobe Flash CS6 dengan menggunakan bahasa pemograman Action Script 3.0 serta perangkat pendukung lainnya.

Tampilan aplikasi merupakan bagian visual dari aplikasi yang dibuat, tampilan yang akan berinteraksi langsung dengan user. Pada halaman ini akan menampilkan desain interface dari setiap menu yang ada pada Aplikasi Multimedia Interaktif Pengenalan Pura Paluang Klungkung Berbasis Android. Gambar 3-6 ini merupakan desain interface dari Aplikasi Multimedia Interaktif Pengenalan Pura Paluang - Klungkung Berbasis Android.

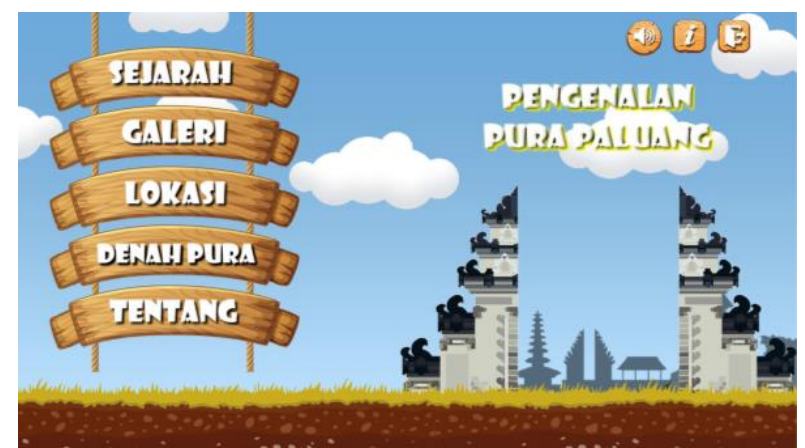

Gambar 3. Tampilan Menu Utama

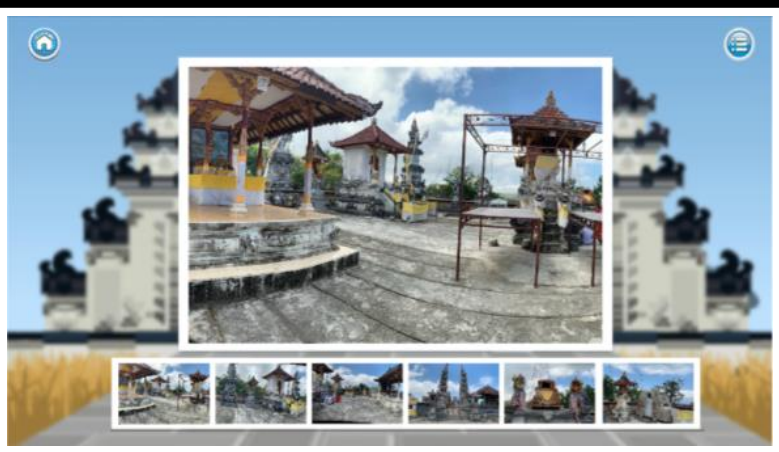

Gambar 4. Tampilan Halaman Galeri

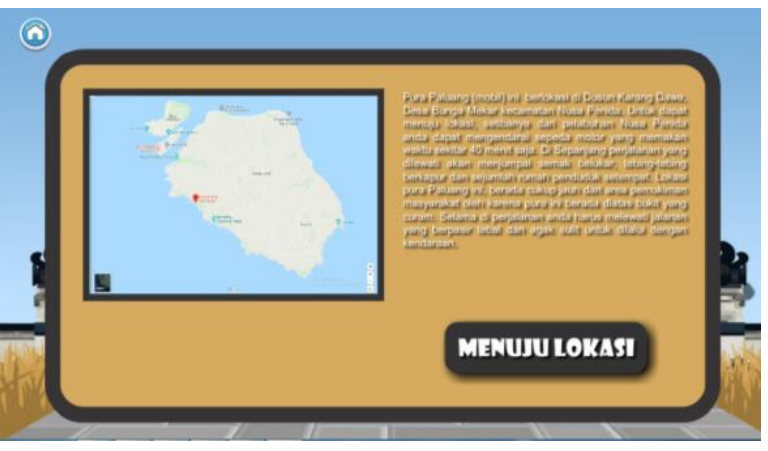

Gambar 5. Tampilan Halaman Peta

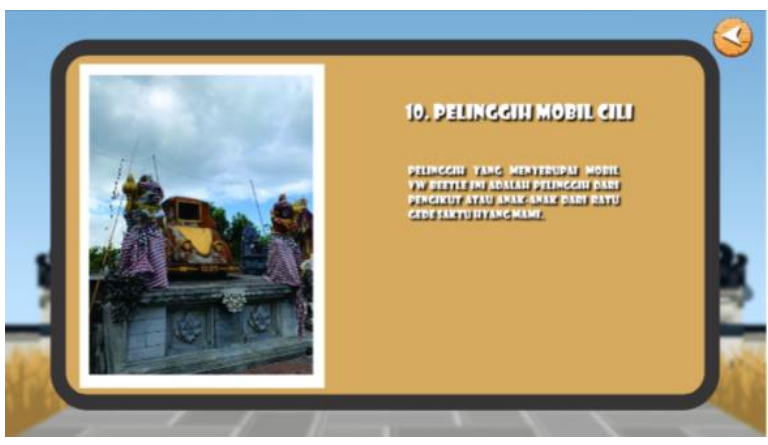

Gambar 6.Tampilan Keterangan Pelinggih

Testing (Pengujian) merupakan tahap pengujian pada sistem aplikasi multimedia, dalam tahapan ini aplikasi di uji dari tingkat keberhasilan atau tidaknya aplikasi yang dibuat. Apabila pada aplikasi di temukan error / bug maka sistem harus ditindak lanjuti untuk di perbaiki, sedangkan jika sistem berjalan sesuai dengan harapan maka aplikasi sudah bisa dianggap selesai $[9,10]$. Pengujian pada aplikasi Multimedia Interaktif Pengenalan Pura Paluang Nusa Penida Berbasis Android menggunakan metode Black-Box Testing.

Hasil pengujian berisi tentang putusan tahap akhir dari rencana pengujian yang telah disusun pada scenario pengujian. Berdasarkan hasil dari pengujian yang dilakukan maka disimpulkan bahwa aplikasi Multimedia Interaktif Pengenalan Pura Paluang Nusa Penida - 
Klungkung Berbasis Android sudah dibangun sesuai dengan yang diharapkan.

\section{Kesimpulan}

Dari penelitian yang berjudul aplikasi "Multimedia Interaktif Pengenalan Pura Paluang Nusa Penida Klungkung" menggunakan Multimedia Interaktif Berbasis Android dapat disimpulkan beberapa hal yaitu sebagai berikut.

Multimedia Interaktif Pengenalan Pura Paluang Nusa Penida - Klungkung dirancang dengan storyboard yang dimana isi dari cerita dihasilkan melalui hasil wawancara langsung dengan Mangku Suar selaku adat Pura Paluang agar bisa berbasis Android.

Aplikasi Multimedia Interaktif Pengenalan Pura Paluang Nusa Penida - Klungkung Berbasis Android dalam pengujian menggunakan metode Blackbox sudah berjalan sesuai dengan yang diharapkan, fungsionalitas aplikasi juga sudah berfungsi dengan baik.

\section{Daftar Rujukan}

[1] K. Wulandari and I. K. Sudarsana, "EKSISTENSI PURA RATU GEDE EMPU JAGATD DESASANGKARAGUNG KECAMATANJEMBRANA KABUPATEN JEMBRANA," J. Penelit. Agama Hindu, vol. 1, no. 2, pp. 252-256, 2017.

[2] S. I. P. Gede, "Pelinggih Mobil di Pura Paluang Nusa Penida: Perspektif Pergulatan Identitas," in Prosiding Seminar Nasional Desain dan Arsitektur (SENADA), 2019, vol. 2, pp. 166-175.

[3] J. Rinaldi, A. M. Rumagit, and A. S. M. Lumenta, "Perancangan Tutorial Penerimaan Mahasiswa Baru Universitas Sam Ratulangi Berbasis Animasi 3D," J. Tek. Elektro dan Komput., vol. 1, no. 4, pp. 1-6, 2012, doi: 10.35793/jtek.1.4.2012.618.

[4] G. H. M. Nasser, Sistem Multimedia. Yogyakarta, 2019.

[5] M. Ali and M. Asrori, Metodologi dan Aplikasi Riset Pendidikan. Jakarta: PT Bumi Aksara, 2014.

[6] Mustika, "Rancang Bangun Aplikasi Sumsel Museum Berbasis Mobile Menggunakan Metode Pengembangan Multimedia Development Life Cycle (Mdlc)," J. Mikrotik, vol. 8 No. 1, no. 1, p. 5, 2018.

[7] S. Barasandji and D. Pawala, "Peningkatan Kemampuan Siswa Membuat Kalimat Tanya melalui Teknik 5w 1h di Kelas IV SD Inpres Lobu Gio," vol. 1, no. 4, pp. 55-66, 2014.

[8] J. Sundari and T. Solihah, "Perancangan Animasi Interaktif Lingkungan Alam Dan Buatan Menggunakan Video Motion," JIKA (Jurnal Inform., vol. 4, no. 2, p. 32, 2020, doi: 10.31000/jika.v4i2.2623.

[9] W. Wibisono and F. Baskoro, "PENGUJIAN PERANGKAT LUNAK DENGAN MENGGUNAKAN MODEL BEHAVIOUR UML," JUTI, vol. 1, no. 1, pp. 43-50, 2002.

[10]Dhega Febiharsa, I Made Sudana and Noor Hudallah3, "Uji Fungsionalitas (Blackbox Testing) Sistem Informasi Lembaga Sertifikasi Profesi (Silsp) Batik Dengan Appperfect Web Test Dan Uji Pengguna," Joined Journal, Vol.1, No. 2, p. 117-126, 2018. 